\title{
Which is More Important? Halal Label or Product Quality
}

\author{
Harie Lutfie \\ School of Economics and Business, Telkom University \\ Bandung, Indonesia \\ Erdita Puspa Puji Suzanti \\ School of Economics and Business, Telkom University \\ Bandung, Indonesia
}

\author{
Osa Omar Sharif \\ School of Economics and Business, Telkom University \\ Bandung, Indonesia \\ osaomarsharif@gmail.com \\ Dini Turipanam Alamanda \\ School of Economics and Business, Telkom University \\ Bandung, Indonesia
}

\begin{abstract}
The purpose of this study is to analyze which one is considered more important by Muslim consumers when they make a purchase decision, halal label or product quality? Wardah cosmetic product was chosen to be the object of the study; samples were taken from as many as 100 people who have joined Wardah Cosmetics' Facebook Fan Page using purposive sampling technique. The data analysis technique used is path analysis. Product quality was found as the more affecting factor for the consumers in purchasing Wardah cosmetic products. Meanwhile, halal label has not significantly been able to influence the consumers in their purchase decisions, but it could enhance Wardah's brand image as the cosmetic products intended for Muslim women. Wardah still has to care and maintain the products quality because it is the driving factor for the consumers to purchase their cosmetics.
\end{abstract}

Keywords—halal label; product quality; brand image; purchase decision

\section{INTRODUCTION}

Competition in the cosmetic industry markets has become more competitive, proven by the existence of many types of domestic and imported cosmetic products circulating in Indonesia. Cosmetics contain a long list of chemicals, most of which are synthetic and petroleum based which can trigger health problems such as skin irritation up to the most severe cancer [1]. Indonesia as a country whose population is predominantly Muslims must be careful when choosing cosmetic products. Muslim consumers need a statement that the products are halal for consumption in accordance with the Islamic Sharia's. Women as the consumers should be more careful in choosing cosmetic not only for their health reasons, but also for the reason of piety which is a necessity for Muslim women. Halal statement on products in Indonesia is in the form of halal label, certified by the Research Institute for Food, Drug and Cosmetic of the Indonesian Ulama Council (LP POM MUI) in cooperation with the Ministry of Health and the Ministry of Religious Affairs [2].

Products quality desired by consumers is related to the benefits they get to meet their needs and how safe the products are for them. If a product is considered to have good quality in the eyes of the consumers, the product will always be sought. Consumers give judgment on a product after they have used it. Then, the consumers can judge it in terms of the product quality. For cosmetic products, the companies must specify the compositions of the product's material mixtures, the expiry period, how to use them and the information that the products have been inspected by the Agency for Food, Drug and Cosmetic Control (BPPOM).

Which is more important for Muslim consumers in Indonesia, halal label or product quality? Wardah cosmetic is one of the cosmetic manufacturers which already owns halal label. Wardah wants to attract consumers to buy the products through three principles, namely Pure and Safe, Beauty Expert, and Inspiring Beauty. The most important principle among the three, in attracting their consumers to buy, is Pure and Safe, Wardah herewith would like to emphasize that their products are made of safe materials and do not contain substances that are prohibited by Islam. It is concluded that Wardah cosmetic products are not only halal but also guaranteed in the quality and safe to be used by women in Indonesia.

Wardah Cosmetic products which have been well known for their halal label and/or good quality will be embedded in the minds of the consumers and create a good and positive image, so that when Indonesian women hear something about Wardah or see the logo then what they have in mind is that Wardah is one option of cosmetic products which should be owned by them. Based on the survey of the Institute of Business (IOB), there was an increase in the sales of Wardah cosmetic products from 2011 to 2012 [3]. In 2011, the products of Mustika Ratu won the first position of the biggest sales in the category of cosmetics and Wardah was in the second place. But in 2012, Wardah took the first position and Mustika Ratu was conversely in the second position. In this study, what made the increase of Wardah's sales will be examined whether it was caused by the factor that Wardah has already had halal label or it was because of the products quality. 
Another very important aspect is the image of the brand itself. Reference [4] states that brand image is the consumers perception and trust, reflected in the association taking place in the memory of the consumers concerning the brand of a product they see, think and imagine. Creating the right brand image for a product would be very useful for the marketers because brand image will influence consumer judgments on alternative brand expected. It will not only be able to meet the consumers' needs, but can also provide better and guaranteed satisfaction. The better the brand image attached to the product, the more attracted the consumers in buying the product. Reference [5] states that consumers always choose brands based on their images. If the consumers do not have any experience with a product, they tend to "trust" the preferred or famous brand. Positive brand image is related to customer loyalty, trust in the brand's value, and willingness to look for the brand. A positive brand image also helps increase the consumers' interest against various marketing activities of the competitors. Wardah's brand image is the cosmetics of Muslim women.

\section{A. Labeling}

\section{LITERATURE REVIEW}

According to [6] label ranges from simple markers affixed to the product to a complicated series of letters that becomes a part of the package. Label has several functions. At least, a label indicates the product or brand, illustrates several things about the product and what company made it, where it was made, when it was made, its contents, direction to use it and how to use it safely. Lastly, label can help promote the product and support the positioning. Reference [6] states that label has three main functions: 1 . To identify a product or brand; 2 . To determine the product's class; 3 . To describe what company, when, where the product was made and what is contained in it.

According to [7] label is divided into three classifications, namely: 1) Brand label, the brand given to a product or listed on the package; 2) Descriptive label, a label that gives an objective information concerning the use, composition or process of production, attention or care, and product performance and other characteristics associated with the product; 3) Grade label, label that identifies the product's assessed quality (product's judged quality), represented by a letter, number, or word, e.g. fruits in cans labeled as quality A, $\mathrm{B}$, and $\mathrm{C}$.

\section{B. Halal Label}

Halal certification and halal label are two different things but they have relations to one another. Halal certification can be defined as a systematically testing activity to determine whether a good produced by a company has fulfilled halal requirements. The result of halal certification activity is the issuance of halal certificate if the intended product has met the requirements for halal products. Halal certification is done by agencies that have authority to carry it out. The ultimate purpose of halal certification is to have a legally formal recognition that a product issued has complied with halal requirements.

While halal labeling is an activity of affixing the written statement of halal on a product's package to indicate that the product is a halal product. In Indonesia the authoritative institution in charge of issuing halal certification is the Indonesian Ulama Council (MUI), which is technically handled by the Research Institute for Food, Drug and Cosmetics (LPPOM) and managed by the Food and Drug Supervisory Agency (BPOM).

In its implementation in Indonesia, halal labeling activity has been done earlier before halal certification exists and the technical regulation governing this labeling process is the joint decision between the Minister of Health and Minister of Religious Affairs No. 427 / Men.Kes / SKBMII / 1985 (No.68 of 1985) concerning the Inclusion of halal statement On Food Labels.

\section{Product Quality}

According to [6] product quality is one of the main positioning means of marketers. Quality has a direct impact on the performance of the product or service. Therefore, quality is closely linked to the value and customer satisfaction. In a narrower sense, quality can be defined as "free from damage." However, most customer-centered companies have stepped ahead far beyond this narrow definition.

In reference to the statement, it can be concluded that the quality of a product is closely linked to the strengths and weaknesses of a product. The quality of a product is one of consumer considerations in choosing a product to be purchased. Therefore, the company is required to be able to produce quality goods or services, so it can compete with competitors. If the quality of the product is as expected, then the consumer will buy it.

Meanwhile, according to [8] there are eight dimensions of product quality, namely: 1) Performance which is the principal operating characteristics of the core products purchased; 2) features or additional characteristics (features), which is a secondary or complementary characteristics; 3) Reliability which is less likely to be damaged or failed to use; 4) Conformance to specifications, namely how far the characteristics of the design and operation fulfills the previously determined standards; 5) Durability, which has something to do with how long the product can be used; 6) Serviceability, involves the handling of complaints satisfactorily. The services provided are not only limited prior to the sale, but also during the sales process and after the sales; 7) Aesthetics, which is the appeal of the product to the senses, for example: the physical shape, model, artistic design, and so on; 8 . The perceived quality which is the image and reputation of the product as well as the corporate responsibility to it.

\section{Brand Image}

In accordance with [4] Brand image can be defined as the perception about a brand that is reflected through brand associations contained in one's memory. It also means, the elements of brand image are closely related to brand association. According to [9] brand association is all things in one's memory about a brand. A variety of associations that a person remembers can form brand image in the mind of the person.

According to [4], a positive brand image is created by a marketing program that connects strength, favorability 
(excellence) and uniqueness. The elements of brand image in connection with the brand association according to [4] are as follows:

\section{a. Strength of Brand Association}

Strength can provide the information about a product and the trust has been built up based on the attributes of the brand which means something that depicts the character features of a product or service and the brand advantages such as personal value and meaning of the product that the consumers are attached to.

\section{b. Favorability of Brand Association}

Favorability of Brand Association is created by convincing the target market that the brand has relevant benefits and can satisfy their needs and desires to form their positive brand attitude. Favorability depends on two things: the desirability and deliverability. Desirability means to what extent the brand of the product delivered by the marketing communication program can meet the desires or expectations of the target market. Desirability depends on three factors, among others:

1) The compatibility level of the brand in the eyes of the target market.

2) The specificity level of the brand in the eyes of the target market.

3) The confidence level of the brand in the eyes of the target market.

Meanwhile, deliverability is the extent to which the brand of products presented by the marketing program can be successfully delivered to the target market.

Deliverability depends on three factors, among others:

1) The ability of the marketing communication program in demonstrating the benefits of the brand.

2) The possibility of the marketing communication program in influencing the target audience in the present or the future.

3) The Resilience of the communicated brand image through the marketing communication program in the long term.

Reference [4] reveals similar things briefer, favorability of Brand Association is the excellence of brand association in the ability to meet the factors of desirability (fit, excellent and reliable) and deliverability (a potential ability of a product when it is given, communicate the results in the future; and the ability to maintain long term results).

\section{c. Uniqueness of Brand Association}

The uniqueness of brand association has a sustainable competitive advantage or "unique selling proposition" that gives consumers a compelling reason why they should buy it.

Reference [10] states successful brand image can be considered as a combination of three elements, namely: a good product, a distinct identity and an added value. Developing a brand is started by having an effective product. Next, the product should be given a different identity so that customers can identify and request it by name, it is usually measured by the awareness that is deliberately or inadvertently built. Lastly, the most important thing is a successful brand must have the added value in convincing customers that the brand has a better quality or more desirable than similar products from other competitors.

\section{E. Purchase Decision}

The five stages in the process of purchasing a product according to [6] are described as follows:

1) Need recognition, buyers aware of a problem or need. Needs can be triggered by the internal or external stimuli that is high enough to be a boost.

2) Information search, interested consumers will want to look for more information, enlarge their attention or search the information actively. Consumers can obtain information from several personal sources.

3) Alternative evaluation, The process in which consumers use the information to evaluate the alternative brands in a bunch of brand choices. Rank the brands and make intention to buy them.

4) Purchase decision, consumers buy the most preferred brand, but influenced by two factors: the attitude of others and the unexpected situational factors.

5) Post-purchase behavior, consumers take further action after the purchase based on their satisfaction or dissatisfaction.

\section{F. The Relation between Halal Label and Brand Image}

A product that has been labeled halal indicates that it has the strength and excellence [4]. The strength and excellence will establish a positive brand image. Positive brand image will be firmly inveterate in the minds of the consumers that the product will also have a strong positioning in the market segment that these products are targeting [6].

\section{H1. Halal Label affects Brand Image}

\section{G. The Relation between Product Quality and Brand Image}

A good quality product indicates that the product has strengths and excellence to survive and compete against the competitors in the market [4]. Similarly with halal label, product quality is one of the added values of a product. The value can be created by the attention of the customers at the brand and the brand image of the product in their minds. Having a positive brand image in the minds of the consumers makes the product has a strong positioning to compete in the market [6].

\section{H2. Product Quality affects Brand Image.}

\section{H. The Relation between Brand Image and Purchase Decision}

The consumer's decision is closely linked to the information they have and the various factors that influence their knowledge about the product to be bought. Product that has a strong brand image in their minds will become the affecting factor for the consumers in making purchase decision [10]. Besides, brand image is able to increase the market share and sales of the product [11].

H3. Brand Image affects the Purchase Decision 


\section{The Relation between Halal Label and Purchase Decision}

The correlation between halal label and consumer purchase decision process takes place when a product is labeled halal by the MUI, it gives a positive value to the consumers and the product itself. Considering that the majority of Indonesian citizens are Muslims, halal label on a product is very important in order to make sure that the product is indeed halal because it has been officially certified and recognized by MUI. Halal label itself is included within the consumer's consideration in the process of making a purchase decision, precisely at the stage of finding information about the product. So if the information about the product is clear and complete, then the consumers have no doubt of the product they intend to buy and finally they decide to buy it [6].

H4. Halal Label affects the Purchase Decision

\section{J. The Relation between Product Quality and Purchase Decision}

Similarly to halal label, product quality is very important in the process of consumer's purchase decision. Before consumers decide to buy a product, they should find out in advance the quality of the product. Usually the quality of a product can be seen from the composition of the product on the package. Besides that, consumers can find out the quality of a product from its reviews or testimonials. Therefore, product quality is very influential on the consumer's purchase decision process, precisely at the second stage which is the search for the information [6].

\section{H5. Product Quality affects the Purchase Decision}

\section{Methodology}

The conceptual model in this study uses four constructs which are halal label, product quality, brand image, and the purchase decision. Halal label and good product quality will establish a positive brand image [6]. Product with a strong brand image in the minds of consumers will become a factor affecting the consumer's purchase decision [10].

Fig 1 shows that the purchase decision can be predicted by two independent variables, namely the halal label and product quality. Halal label and product quality can also establish a positive brand image, and brand image is a predictor for the purchase decision that makes it as an intervening variable. From those independent variables, halal label and product quality, which one can create a more positive brand image? and which is deemed more important by the consumers before they make a purchase decision?

The instrument used to measure halal label is built based on the definition taken from the joint decision between the Minister of Health and Minister of Religious Affairs No. 427 / Men.Kes / SKBMII / 1985 (No.68 of 1985) concerning the inclusion of halal statement On Food Labels. Halal label is the inclusion of a writing statement of halal on a product package to indicate that the product is halal, so that the consumers are certain and sure that the product does not contain anything that is not halal and is also produced in a halal way.

The instrument to measure product quality is the dimensions of product quality according to [8] there are eight dimensions, namely: performance, features, reliability, and conformance to specification, durability, serviceability, aesthetics, and perceived quality. Instrument for measuring brand image is based on the previous research conducted by [4]. Instrument to measure purchase decision is based on the five purchase decision processes according to [6].

All instruments which consist of 48 items were measured using four ordinal scales, all of the instruments are valid and reliable. Samples were taken from as many as 100 people who has joined the Facebook Fan Page of Wardah Cosmetics using purposive sampling technique. The data analysis technique used is path analysis.

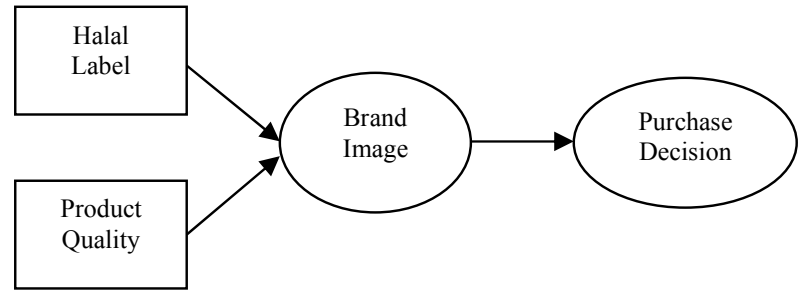

Fig 1. Conceptual model 
TABLE I. OVERALL MEASUREMENT MODEL

\begin{tabular}{|c|c|}
\hline Variable $\mid$ Indicator & Item \\
\hline \multicolumn{2}{|l|}{ Halal Label } \\
\hline \multirow{2}{*}{$\begin{array}{l}\text { Noting the inclusion of } \\
\text { halal statement on the } \\
\text { package of Wardah } \\
\text { cosmetic products }\end{array}$} & $\begin{array}{l}\text { I noticed the halal label on the packages of } \\
\text { Wardah cosmetic products }\end{array}$ \\
\hline & $\begin{array}{l}\text { I pay attention to the statement of the halal label } \\
\text { on the packages of Wardah cosmetic products. }\end{array}$ \\
\hline \multirow{2}{*}{$\begin{array}{l}\text { Noting the location of } \\
\text { halal label on every } \\
\text { product of Wardah } \\
\text { cosmetics. }\end{array}$} & $\begin{array}{l}\text { I think the location of halal label on the } \\
\text { packages of Wardah cosmetic products is easy } \\
\text { to find. }\end{array}$ \\
\hline & $\begin{array}{l}\text { I think the inclusion of halal label on the } \\
\text { packages of Wardah cosmetic products is ideal }\end{array}$ \\
\hline \multirow{2}{*}{$\begin{array}{l}\text { Provide certainty that } \\
\text { Wardah cosmetic } \\
\text { products are safe to use }\end{array}$} & $\begin{array}{l}\text { I am sure the materials used by Wardah } \\
\text { cosmetic products are safe }\end{array}$ \\
\hline & $\begin{array}{l}\text { I am convinced that Wardah cosmetic products } \\
\text { do not damage the skin of my face }\end{array}$ \\
\hline $\begin{array}{l}\text { Provide safety } \\
\text { guarantee for the } \\
\text { consumers of Wardah } \\
\text { cosmetic products }\end{array}$ & $\begin{array}{l}\text { By the existence of halal label on Wardah } \\
\text { cosmetic products, I am sure that the materials } \\
\text { used have been tested safety }\end{array}$ \\
\hline \multicolumn{2}{|l|}{ Product Quality } \\
\hline \multirow[t]{2}{*}{ Performance } & $\begin{array}{l}\text { I think Wardah cosmetic products are mild } \\
\text { when used on the skin of my face }\end{array}$ \\
\hline & $\begin{array}{l}\text { I feel that Wardah cosmetic products fit with } \\
\text { my facial skin }\end{array}$ \\
\hline \multirow{3}{*}{ Features } & $\begin{array}{l}\text { I like the product combination of Wardah } \\
\text { make-up series }\end{array}$ \\
\hline & $\begin{array}{l}\text { I like the color variants of each make-up series } \\
\text { of Wardah cosmetic products }\end{array}$ \\
\hline & $\begin{array}{l}\text { By using Wardah cosmetic products, I feel that } \\
\text { my face still looks natural. }\end{array}$ \\
\hline Reliability & $\begin{array}{l}\text { There is no irritation on my face after using } \\
\text { Wardah cosmetic products }\end{array}$ \\
\hline \multirow{2}{*}{$\begin{array}{l}\text { Conformance to } \\
\text { specification }\end{array}$} & $\begin{array}{l}\text { I think the shape of Wardah make-up series is } \\
\text { ideal so that I can put it in my bag }\end{array}$ \\
\hline & $\begin{array}{l}\text { I think the shape of Wardah make-up series is } \\
\text { easy to take anywhere }\end{array}$ \\
\hline \multirow{2}{*}{ Durability } & $\begin{array}{l}\text { Wardah Make-up series is durable when I use } \\
\text { every day. }\end{array}$ \\
\hline & $\begin{array}{l}\text { The expired period of Wardah make-up is long } \\
\text { enough so that I can use it for months }\end{array}$ \\
\hline \multirow{3}{*}{ Serviceability } & $\begin{array}{l}\text { I think that Wardah's counter sale clerks are } \\
\text { very friendly }\end{array}$ \\
\hline & $\begin{array}{l}\text { I think that the sale clerks at Wardah's counter } \\
\text { explain the products in detail }\end{array}$ \\
\hline & $\begin{array}{l}\text { I guess Wardah's customer service responds } \\
\text { quickly to serve their customers }\end{array}$ \\
\hline \multirow{2}{*}{ aesthetics } & $\begin{array}{l}\text { I think the package of Wardah's make-up series } \\
\text { is very unique. }\end{array}$ \\
\hline & $\begin{array}{l}\text { I think the packaging color of Wardah's make- } \\
\text { up series is very attractive }\end{array}$ \\
\hline Perceived quality & I think Wardah has a good quality product \\
\hline \multicolumn{2}{|l|}{ Brand Image } \\
\hline Strength & I think the safety of the cosmetic products is the \\
\hline
\end{tabular}

\begin{tabular}{|c|c|}
\hline & strength of Wardah \\
\hline & $\begin{array}{l}\text { I think having the Islamic image is the strength } \\
\text { of Wardah }\end{array}$ \\
\hline & $\begin{array}{l}\text { Since Wardah uses safe basic ingredients in the } \\
\text { cosmetic products, it convinces me that the } \\
\text { products have good reputation }\end{array}$ \\
\hline & $\begin{array}{l}\text { I believe by using safe basic ingredients in } \\
\text { Wardah cosmetic products makes my skin } \\
\text { naturally more beautiful }\end{array}$ \\
\hline \multirow{3}{*}{ Favorability } & $\begin{array}{l}\text { I reckon the natural concept of Wardah } \\
\text { cosmetic products fits my liking }\end{array}$ \\
\hline & $\begin{array}{l}\text { I feel that the good quality in Wardah cosmetics } \\
\text { fits my personality }\end{array}$ \\
\hline & $\begin{array}{l}\text { I feel that halal and quality cosmetic products } \\
\text { of Wardah fit my needs }\end{array}$ \\
\hline \multirow{2}{*}{ Uniqueness } & $\begin{array}{l}\text { I find the concept of Wardah's natural cosmetic } \\
\text { products is an interesting uniqueness }\end{array}$ \\
\hline & $\begin{array}{l}\text { I think the color variants of Wardah cosmetic } \\
\text { products are very suitable with the skin of } \\
\text { Indonesian women }\end{array}$ \\
\hline \multicolumn{2}{|l|}{ urchase Decision Process } \\
\hline \multirow{3}{*}{ Need recognition } & $\begin{array}{l}\text { I want cosmetic products and one of them is } \\
\text { Wardah cosmetic product }\end{array}$ \\
\hline & $\begin{array}{l}\text { I need cosmetic products and one of the is } \\
\text { Wardah cosmetic product }\end{array}$ \\
\hline & $\begin{array}{l}\text { I realize Wardah cosmetic products fit my } \\
\text { needs }\end{array}$ \\
\hline \multirow{3}{*}{ Information search } & $\begin{array}{l}\text { I was looking for cosmetic products } \\
\text { information I needed, one of them was that of } \\
\text { Wardah cosmetic product }\end{array}$ \\
\hline & $\begin{array}{l}\text { I was looking for cosmetic product reviews that } \\
\text { I needed one of them was those of Wardah } \\
\text { cosmetic products }\end{array}$ \\
\hline & $\begin{array}{l}\text { I looked for the information about how to use } \\
\text { cosmetic products, one of them was about } \\
\text { Wardah cosmetic products }\end{array}$ \\
\hline \multirow{3}{*}{ Alternative evaluation } & $\begin{array}{l}\text { I compared the color variants of Wardah } \\
\text { cosmetic products I would buy with those of } \\
\text { other brands }\end{array}$ \\
\hline & $\begin{array}{l}\text { I considered various brands of cosmetics one of } \\
\text { them was Wardah cosmetic products }\end{array}$ \\
\hline & $\begin{array}{l}\text { I looked for the information about the benefits } \\
\text { of cosmetic products one of them was about } \\
\text { Wardah cosmetic products }\end{array}$ \\
\hline \multirow{2}{*}{ Purchase decision } & I decided to buy the product of Wardah \\
\hline & I decided to use Wardah products \\
\hline \multirow{4}{*}{$\begin{array}{l}\text { Post purchase } \\
\text { behavior }\end{array}$} & I feel satisfied after using Wardah products \\
\hline & I re-purchased Wardah cosmetic products \\
\hline & $\begin{array}{l}\text { I will be a regular customer of Wardah } \\
\text { cosmetic products }\end{array}$ \\
\hline & I'll try other Wardah products \\
\hline
\end{tabular}




\section{RESUlt AND DisCUSSION}

TABLE II. PATH ANALYSIS RESULT

\begin{tabular}{|c|l|c|l|c|}
\hline \multicolumn{2}{|c|}{ Hypothesis } & $\begin{array}{c}\text { p- } \\
\text { value }\end{array}$ & Description & $\begin{array}{c}\text { total } \\
\text { effect }\end{array}$ \\
\hline 1 & $\begin{array}{l}\text { Halal label is positively } \\
\text { related to brand image }\end{array}$ & 0.007 & $\begin{array}{l}\mathrm{H} 1 \text { is } \\
\text { supported }\end{array}$ & $31 \%$ \\
\hline 2 & $\begin{array}{l}\text { Product quality is not } \\
\text { related to brand image }\end{array}$ & 0.391 & $\begin{array}{l}\mathrm{H} 2 \text { is not } \\
\text { supported }\end{array}$ & 0.00 \\
\hline 3 & $\begin{array}{l}\text { Brand image is not related } \\
\text { to purchase decision }\end{array}$ & 0.051 & $\begin{array}{l}\text { H3 is not } \\
\text { supported }\end{array}$ & 0.00 \\
\hline 4 & $\begin{array}{l}\text { Halal label is not related to } \\
\text { purchase decision }\end{array}$ & 0.371 & $\begin{array}{l}\text { H4 is not } \\
\text { supported }\end{array}$ & 0.00 \\
\hline 5 & $\begin{array}{l}\text { Product quality is } \\
\text { positively related to } \\
\text { purchase decision }\end{array}$ & 0.028 & $\begin{array}{l}\text { H5 is } \\
\text { supported }\end{array}$ & $15 \%$ \\
\hline
\end{tabular}

Halal label positively influences on brand image, Wardah brand image as the cosmetics intended for Muslim women is influenced one of them by the halal label which contributes by $31 \%$. While the quality of the product does not affect the brand image, which means Wardah brand image is influenced more by the halal label than the quality of the products. Consumers feel that the inclusion of halal label on the packaging of Wardah cosmetic products is ideal and they believe that Wardah cosmetic products do not damage the skin of their faces.

Brand image that usually affects the purchase decision has no effect on the purchase decision for Wardah cosmetics. Purchase decision is influenced more by the products quality. Products quality can affect consumers in deciding to buy Wardah cosmetic products. While halal label and brand image do not affect the purchase decision.

\section{CONCLUSION}

Product quality is the factor that is more influencing for the consumers to purchase Wardah cosmetic products. Halal label cannot significantly influence consumers in their purchase decision on Wardah cosmetic products; however, the halal label can enhance Wardah brand image as the cosmetic products intended for Muslim women.

Wardah with its good image, one of which is the inclusion of halal label on their product packages, still has to care and maintain the products quality because it is the driving factor for consumers to purchase Wardah cosmetics.

\section{References}

[1] A. Ratnadinata, "Hampir separuh kasus penyakit kulit karena produk kosmetik," [online] http://health.detik.com/read/2012/03/05/110024/185, March 2012

[2] L. Sukmawati, "Analisis pengaruh label halal terhadap brand switching (kasus produk kosmetik wardah)," Institut Pertanian Bogor, unpublished.

[3] SWA, "Peningkatan penjualan produk kosmetik Wardah," SWA edition XXVIII 27 Agustus - 5 September 2012.

[4] K. L. Keller, Strategic brand management: building, measuring, and managing brand equity, New Jersey: Pearson Education, 2008.

[5] L.G. Schiffman, and L.L. Kanuk, Consumer behavior, New Jersey: Prentice-Hall International, Inc., 2010.

[6] P. Kotler, and G. Amstrong, Principles of Marketing, New Jersey: Pearson Education, 2008.

[7] W.J. Stanton, Fundamentals of marketing, Sydney: McGraw-Hill, 1984.

[8] F. Tjiptono, and G. Chandra, Service, Quality, and Satisfaction, 3rd ed, Jogjakarta: ANDI, 2011

[9] J.L. Aaker, "Measuring brand equity: across product and markets," California Management Review, vol. 38 no. 3, 1996, pp. 160, Proquest Education Journals database.

[10] Sumarwan, Riset pemasaran dan konsumen, 2nd ed, Bogor: IPB Press, 2012.

[11] M.F. Sial, A. Gulzar, N. Riaz, and B. Nawaz, "Impact of labeling anda packaging on buying behavior of young consumers with mediating role of brand image," Interdisciplinary Journal of Contemporary Researh in Business, Vol. 3 No. 1, pp. 1-8, ijcrb.webs.com, 2011. 